\title{
Investigating the Effect of Convenience, Accessibility and Reliability on Customer Satisfaction in the Nigeria Banking Industry
}

\author{
Mohammed Sani Abdullahi ${ }^{1}$, Bashir Mikail Usman ${ }^{2}$, Fatima Binta Salisu , \\ Yusuf Suleiman Muhammad ${ }^{4}$ \\ ${ }^{1}$ Department of Business Administration, Faculty of Social and Management Sciences, Yusuf \\ Maitama Sule University Kano State, Nigeria. \\ ${ }^{2}$ Department of Actuarial science, Faculty of Social and Management Sciences, Federal \\ University Dutse, Jigawa State, Nigeria. \\ ${ }^{3 \& 4}$ Department of Business Administration and Management, School of Management Studies, \\ Kano State Polytechnic, Nigeria. \\ Email: abdulmohdsani@gmail.com
}

\begin{abstract}
This study investigates the effect of convenience, accessibility and reliability on customer satisfaction in the Nigeria banking industry. The target populations of the study are customers of Jaiz Bank, BUK Road Branch in Kano State, Nigeria and the stated bank branch serves as the scope of the study. The population of the study consists of 10,580 customers of the focused bank in question, and 371 respondents make up the study sample size and it was captured out of the stated population which was obtain through research advisors table of sample size determination. Structured questionnaire was employed as the method of data collection, while regression analysis was employed as the method of data analysis that tests the hypothesized hypotheses of the study. The result indicates that electronic accessibility and convenience has significant and positive effect on customer satisfaction. The result of the study also found that electronic reliability has negative effect on customer satisfaction. This study recommends that banks should enlighten and educate customers judiciously on the use of electronic services such as SMS (Mobile) banking, web/internet banking and e-switch, POS banking services that are not well patronized. Internet banking should be well developed in other to face competition in the banking industry and maintain profit.
\end{abstract}

Keywords: Accessibility Convenience, Customer Satisfaction, and Reliability.

\section{Introduction}

Electronic banking products and services are prime significance for banks to work and stay in a worldwide aggressive condition. E-banking benefit depends on the utilization of new technology to give different banking services straightforwardly to clients all day and all night. Banks offer an extensive variety of these services that can be utilized by electronic 
Pakistan Journal of Humanities and Social Sciences, 6(3), 2018

instruments, for example, ATM, phone, cards, TV banking, point of sales and Internet (Ammar, 2012). CBN (2003) reports following e-banking are accessible in the Nigerian banking framework: ATM, smart cards, phone banking, personal computer (PC) banking, and web banking. Banks need to make changes in support of address client issues by giving an incredible service to clients, through e-banking product (Al-Hajri, 2008). It is essential for banks to offer services electronically to separate themselves from contenders. Banks need to give information to clients on different contending services, which make it conceivable to analyze them and afterward select the one that best meets client prerequisites (Almazari \& Siam, 2008). Banks are strife for surviving and they have to draw in their clients in various routes through giving helpful, open and worthy services of products to their clients (Yan Ma \& Ding, 2010).

Development of electronic banking in a nation relies upon numerous variables, for example, achievement of web access, new online banking features, family unit development of web use, legitimate and administrative system. E-banking can offer speedier, faster and reliable services to the clients for which they might be generally fulfilled than that of manual system of banking. E-banking framework not just creates most recent reasonable return; it can show signs of improvement dealings with clients (Yusuf \& Bala, 2015). The method of reasoning behind this exploration is to perceive and measure the impact of e-banking preparation on consumer satisfaction in the Nigerian banking industry. E-banking was received by banks to enhance their service conveyance, decongest lines in the banking lobby, empower clients withdraw money all days, help worldwide payment and settlement, track individual banking transaction ask for online explanation, or significantly transfer deposit to third party record (John \& Rotimi, 2011). In spite of the exertion of banks to guarantee that clients receive the rewards of e-banking, the bank is met with grievances from clients as regards, breaking down Automated Teller Machines (ATMs), network downtime, online robbery and misrepresentation, non-accessibility of financial services, payment of concealed cost of electronic banking like Short Message Services (SMS), for sending alarm, compulsory procurement of ATM cards, non-worthiness of Nigerian cards for universal exchange among others, and in the meantime most e-banking framework in today monetary establishment are not convenience, reliable and accessible with that consumer satisfaction as what they expect (John \& Rotimi, 2011).

Likewise regardless of the development of web technology acknowledgment, some Nigerian monetary establishments are yet to adopt web technology (Yusuf, 2015). The 
hesitance of web technology selection by banks proposes that managers see the expenses of web technology appropriation to exceed the advantages. This can possibly be clarified by dread of the results of failure in the case of high as well as client's dissatisfaction. The utilization of technology frames the spine for better outcomes in banking system. This is verbalized in the HSBC report (2000), which expressed that advantages from information technology are in excess of three times its cost. The present banking circumstance requests constant development so as to meet the desires and goals of the regularly requesting clients.

However, these advancements in the Nigerian banking industry appear not to have accomplished their point as far as consumer satisfaction and minimization of business hazard. Long lines are still found in the banking corridors, bank clients still handle excessively money, and individuals barely discuss the improvement of electronic banking in Nigeria. The issue here is: are clients truly enjoying these services? Identified with this issue, experimental confirmation infers that clients' support for and response to a specific product rely upon their level of comprehension of what the product can do and what they remain to benefit (Balachandher, 2001). In this association, based on experimental finding from earlier research it was discovered that convenience, accessibility and reliability are the real misfortune soothing e-banking in monetary establishment in Nigeria. This examination is pointed of discovering the motivation behind why these issues happen and much of the time persevere and afterward to make suggestion base on the result of the investigation.

The main objective of this study is to investigate the effect of electronic banking system on customer satisfaction of Jaiz Bank in Kano State, Nigeria, while the specific objectives are as follows: the first objective is to identify the effect of convenience on customer satisfaction in the Nigeria banking industry. The second objective is to determine the effect of accessibility on customer satisfaction in the Nigeria banking industries. The third objective is to examine the effect of reliability on customer satisfaction in the Nigeria banking industries.

\section{A. Hypotheses of the Study}

The hypotheses of the study are as follows:

$\mathrm{H}_{1}$ : There is significance and positive effect of convenience on customer satisfaction in the Nigeria banking industry.

$\mathrm{H}_{2}$ : There is significance and positive effect of accessibility on customer satisfaction in the Nigeria banking industry. 
$\mathrm{H}_{3}$ : There is significance and positive effect of reliability on customer satisfaction in the Nigeria banking industry.

\section{B. Significance of the Study}

This study is of great significance not just to the banks but also to the customers, regulatory authorities, researchers, economy and the general public. E-banking generally, brings about efficiency in the operations of banks. Which lead to customer satisfaction and minimization of business risk; this study will further provide recommendations on how banks can take advantage of this golden opportunity. The study increases the awareness level of customers and also educates the customers on how to go about getting the best out of electronic banking. The regulatory bodies have some roles to play in improving and developing the level e-banking in the country. This study would more or less enlighten them on how, where and why they should contribute to the development of this new trend. The study serve as a guide for future researchers who is willing to explore or carrying out a similar study, also the study enlighten the people about the benefits of using an electronic means in carrying out banking operations. This will thereby bring about development of the economy in the aspect of e-commerce. Finally, the public benefit from this study as it adds to the body of existing knowledge and the results from this study reflect their needs. On a more general note, the jurisdiction of the research work is within commercial banking industries (financial institution) particularly Jaiz Bank plc zoo road branch in Kano State, Nigeria. The main areas under consideration as far as this research is concerned are E-banking, convenience, accessibility, reliability and customer satisfaction in the Nigeria banking industry.

\section{Literature Review}

\section{A. Customer Satisfaction}

Consumer satisfaction is a measure on how products or services meet or outperformed client desires. In a focused market like the banking industry, it comprises of different procedures went for continuing, meeting or surpassing clients' desires. Saha and Zhao (2005) see clients' fulfillment as an accumulation of result of recognition, assessment and mental responses to the utilization involvement with a product or service. At the end of the day, it is an aftereffect of an intellectual and full of feeling assessment where some utilization standard is contrasted with the really perceived performance. Along these lines, if the performance perceived is not as much as expected, clients will be disappointed, and where the perceived performance surpasses desires, clients will be fulfilled and this would prompt 
positive practices or result (Saha \& Zhao, 2005; Yau, 2007). Umorok (2009) noticed that fulfilled clients would proceed with their support, as well as would continue alluding prospect to the firm and that such ceaseless support is probably going to bring down the maintenance flexibility of the firm. In this way, understanding the level of consumer satisfaction is critical to the bank since fulfillment in shopper/consumer settings adds up to convictions and considerations about the results of buying.

\section{B. Electronic Banking}

E-banking includes the arrangement of banking services and products by banks to their clients through electronic medium. This definition likewise stretches out to the utilization of information communication technology (ICT) by banks to give benefits and oversee client relationship more rapidly and most satisfactory. E-banking covers both personal computer (PC) and phone banking (Hurlin, 2003; Mirada, 2009). For some banks, slant to e-banking services enhances client services while nearly welding clients to the bank. The reception of e-banking is likewise observed as another strategy for growing client base and to likewise check the forceful exertion made by conventional banking establishments (Baten \& Kamla, 2010). E-banking, accordingly, incorporates frameworks that empower financial related organizations, clients, people and organizations to access accounts, execute business, and get information on financial products and services through public or private systems. Client's access e-banking services by utilizing electronic gadgets, for example, a personal computer (PC), personal digital assistance (PDA), automated teller machine (ATM) and telecommunication routes. 'Closed' private network limit access to members (financial institutions, clients, traders, and third party providers) bound by concurrence on the terms of enrollment (Culiberg et al., 2010).

Gao and Owolabi (2008) indicate that the present important components deciding the appropriation of web banking in Nigeria incorporate the level of mindfulness or consideration, the openness to personal computers (PCs) and the Internet, comfort, privacy, costs, and the accessibility of information and support concerning web banking. The presentation of web banking service is encouraged by the bank's notoriety regarding size, mindfulness and confide in consciousness of service and its advantages in type of the measure of data a client has about Internet banking and its advantage may critically affect the reception of Internet banking (Jaruwachirathanakul \& Fink, 2005; Al-Somali et al., 2008). 
Convenience, accessibility and reliability are the dimensions of electronic banking that make up the independent variables of the study.

\section{Convenience}

Convenience is a dimension of e-banking that enables customers to access ebanking services at anytime and anywhere (Kumbhar, 2011). E-banking offers customers 24/7 banking services. E-banking customers are able to check their account balances, pay bills, apply for loan, trade securities and conduct other financial transactions. (Kumbhar, 2011). Convenience is a relative concept, and depends on context. For example, automobiles were once considered a convenience, yet today are regarded as a normal part of life (Nupur, 2010).

\section{Accessibility}

Accessibility defines as the ability of users to access information and services from the web which depends on many factors. These include the content format; the user's hardware, software and settings; internet connections; the environmental conditions and the user's abilities and disabilities (Godwin-Jones 2001; Hackett and Parmanto, 2009). The term "web accessibility" generally relates to the implementation of website content in such a way as to maximize the ability of users with disabilities to access it. For example, providing a text equivalent for image content of a web page, allows users with some visual disabilities access to the information via a screen reader (Musiime \& Ramadhan, 2011). The techniques and approaches that create more accessible web pages for people with disabilities also address many other access issues such as download speed and discoverability (Godwin-Jones 2001; Hackett et al, 2004; Hackett and Parmanto, 2009).

\section{Reliability}

Reliability explains the promptness of delivering e-banking service in an accurate way and in line with advertised attributes (Jun \& Cai, 2001). Reliability is the level of transaction security, promptness and focus on the elements that may contribute to user trust. Reliability is established in some studies as a key factor that most customers consider before and even during usage of e-banking service. According to Al-Hajri (2008) success of electronic banking depends on electronic banking service and reliability. Reliability is established in some studies as a key factor that most customers consider before and even during usage of electronic banking service (Ammar, 2012).

\section{Theory Supporting the Study}


Innovation Diffusion Theory (IDT) was developed and introduces by Roger in 1983 discloses people's zeal to embrace technology as a methodology to play out a conventional action. The ultimate factors which decide the appropriation of advancement at all level are the following: relative favorable position, similarity, many-sided quality, trial ability and discernibleness. It is worried about the way in which another technology thought, antiquity or procedure, or another utilization of old one, transients from creation to utilize. The phases through which a technology development passes are: learning (presentation to its reality, and comprehension of its capacities); influence (the shaping of an ideal state of mind to it); choice (pledge to its selection); usage (putting it to utilize); and affirmation (fortification in view of positive results from it). Early clients generally are more highly educated, have higher societal position, are more open to both broad communications and relational channels of correspondence, and have more contact with change specialists. Broad communications channels are generally more essential at the information organize, though interpersonal channels are moderately more critical at the persuasion stage. Growth choices might be discretionary (where the individual or association has a genuine chance to accept or reject the thought), aggregate (where a choice is by agreement among the individuals from a framework), or specialist based (where a choice is reached by someone else or association which has essential power, status or specialized mastery).

Critical parts in the growth procedure include: supposition pioneers (who have moderately visit casual impact over the conduct of others); change specialists (who decidedly impact development choices, by mediating between the change agency and the significant social framework); change associates (who supplement the change operator, by having more concentrated contact with customers, and who have less capability validity however more effectively or dependability believability). The change specialist capacities are to build up a requirement for change with respect to the customer to set up information exchange; to analyze the customer issues; to make aim to change in the customer; to make an interpretation of this purpose without hesitation; to settle reception and forestall discontinuance; and to move the customer from reliance on the change agent to self-reliance. This theory truly bolsters the examination regarding given its bearing/direction.

\section{Review of Empirical Studies}

Khalif and Alzubi (2011) carried out study on E - banking functionality and outcomes on customer satisfaction in Jordan. The result of the study showed that adoption of 
(Accessibility convenience) of the E- Banking had a positively effect on consumer satisfaction. Sharma and Malviya (2014) investigated the impact of internet banking service quality on customer satisfaction in Indore district of Madhya Pradesh, Indi. The result reveals that there is a positive impact between service quality dimension and customer satisfaction. Addai et al. (2015) investigated the effect of electronic banking on customer satisfaction in Ghana. The result indicates significant correlation between E-banking and customer satisfaction. Haidar et al. (2011) examine the impact of E-Banking on the profitability of banks in Pakistan. The result of the study revealed that E-Banking increased the profitability of banks. An empirical study by Nupur (2010) investigated the impact of E-Banking on customer satisfaction in Bangladesh. The result of the study revealed that responsiveness, assurance, empathy tangibles, reliability, are the core service quality dimension for customer satisfaction on the banking.

Akindele and Rotimi (2011) evaluate the analysis of e- banking and customer satisfaction in Nigeria. The finding of the study indicate that nexus between electronic banking and customer satisfaction. Another similar study by John et al. (2011) shows significant positive relationship between commerce and E-Banking. Momeni et al (2013) examined the effect of electronic banking on customer satisfaction and loyalty of banks in Tehran. The result of the study revealed that ease of service use website design, security and content has significant effect on customer satisfaction and loyalty. Musa et al (2015) conduct a study to assess on the impact of online banking on the performance of Nigeria banking sector. The result of the study shows that there is a significant relationship between electronic banking and customer satisfaction. Hassan et al. (2013) researched on electronic banking product and performance on listed deposit money banks in Nigeria. The result of the study show that the adoption of electronic banking product (E - mobile and ATM transaction) has positive impact on the performance of Nigerian banks and also the study shows that E-direct and SMS alert has no significant on the performance of the banks.

Anane and Poku (2015) evaluate the impact of internet banking on the Ghanaian economy. The result of the study shows that there is a significant relationship between the proxies of internet banking and the Ghanaian economy. Offel and Nuamah (2016) determine the contribution of electronic banking to customer satisfaction in Ghana. The result of the study revealed that there is a significant relationship between the variable. Okibo and Wario (2010) examine the effect of E-Banking on growth of customer base in Kenya. The result revealed that E-Banking has positive relationship in the growth of the customer. Bolagun et 
al. (2013) investigated the factors influencing the customer satisfaction with e-banking in Nigeria. The study revealed that telephone banking, mobile banking, points of sale terminate smart card, and television banking have a positive influence on customer satisfaction. Saleem and Rashid (2011) conducted a study on the relationship between customer satisfaction and mobile Banking Adoption in Pakistan. The result of the study shows that customer is concern about the security, authenticity and reliability of technology.

Musiime and Ramadhan (2011) examined the effect of internet banking on customer satisfaction in Uganda. The result shows that there is a significant nexus between internet banking (proxies) and customer satisfaction. Ibok and Ikoh (2011) conducted a study to investigate the determinants of customer satisfaction with internet banking service in Nigeria. The result of the study identified significant factor that lead to customer satisfaction. Ali et al. (2016) carried out a research on the moderating effect of convenience towards the relationship between satisfaction and loyalty in Malaysia banking industry. The result of the study show significant nexus between e-banking satisfaction and online loyalty among the internet banking users in Malaysia. The result also found that there is relationship between e-loyalty and e-satisfaction, indicating that there is a constant influence of e-satisfaction towards eloyalty. Another study by Omar et al (2015) determines the influence of reliability of service quality on customer satisfaction in Malaysia. The result of the study shows that there is a strong relationship between quality of service (reliability) and customer satisfaction.

\section{E. Framework of the Study}

In the light of the literature reviewed and the theory supporting the research work, this study conceptualized that convenience, accessibility and reliability positively affects customer satisfaction. The conceptual framework includes the hypothesized relationships between convenience, accessibility and reliability and customer satisfaction, and it is depicted in figure 1.

Figure 1: Conceptual Model 


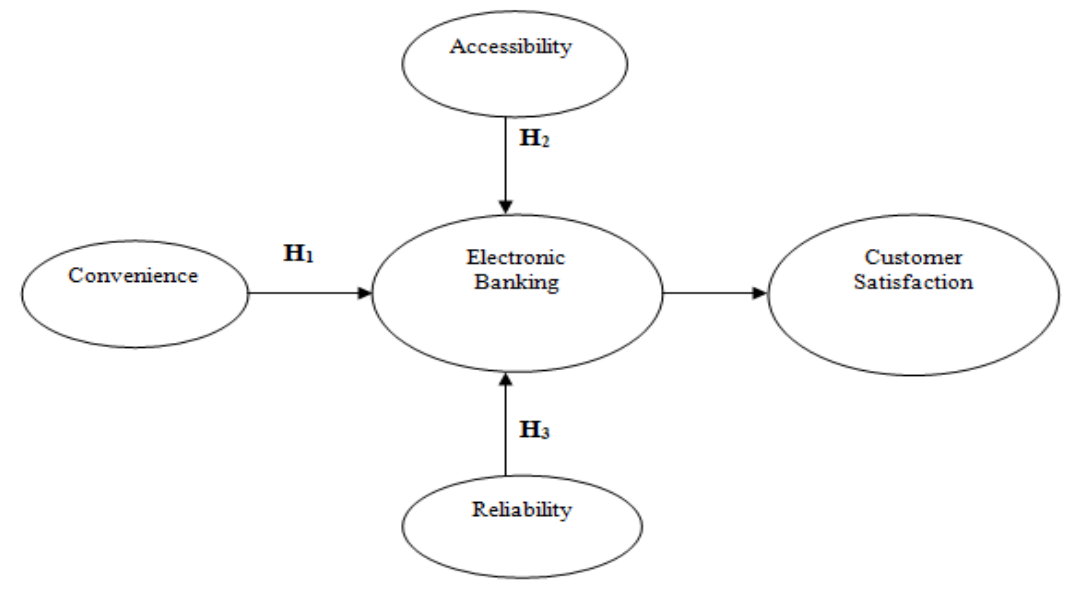

\section{Research Methodology}

Causal research design was used as the research design of the study and target population of the study is base on the customer of Jaiz Bank, BUK Road Branch Kano State, Nigeria. The population of the study consists of 10,580 customers of the focused bank in question. The sample size is obtained using research advisors sample size determination table (Reseach Advisors, 2006). The required sample size was 371 out of the stated population of the study. Non-Probability sampling technique (Convenience Sampling) was used in this study and the research instruments used in this study was purely questionnaire (primary data) given the size of the population. The questionnaire measure the key variables of the research, and a structured questionnaires with close-ended type are to be used for this research work with 1-5 Likert scale which consist of strongly disagree to strongly agree to answer the research questions, and also it is used to measure the responses of the respondents of this study. This study used descriptive and inferential statistics. First, descriptive statistics are to be conducted using frequency and percentages, for the demographic data of the study. Secondly, this study employed multiple regression analysis (Inferential Statistic) in order to test the hypothesized model of the study.

\section{Result and Discussion}

This section presents and discusses the data collected for the study. It covers the survey response, data cleaning which fundamentally include the issues of missing values and outliers. The section also discusses the test of reliability, profile of the respondent. In addition, it presents the regression analysis that tests the hypotheses of the study.

Out of 371 copies of the questionnaire, a total of 360 respondents filled and returned the distributed questionnaire. However, a total of 350 were finally used for the analysis. Specifically, after the data collection, a total of 11 responses were excluded from the analysis 305 
for two (2) main reasons. First, some copies of the questionnaire were incomplete; secondly, outliers have also caused some copies of the questionnaire to be excluded. A total of 350 respondents constitute the sample for this study, which shows a good response rate of $93 \%$ that covers a wide Jaiz Bank plc. Table 1 presents the demographic profile of the respondents. The respondent were asked to explain their demographic information which includes their age, qualification, years of using bank, occupation, gender.

Table 1: Descriptive Profile of the Respondents

\begin{tabular}{|c|c|c|c|}
\hline Demographic Variables & Category & Frequency & Percentage (\%) \\
\hline \multirow{4}{*}{ Age } & $18-25$ & 62 & 17.7 \\
\cline { 2 - 4 } & $26-35$ & 99 & 28.3 .0 \\
\cline { 2 - 4 } & $36-45$ & 80 & 22.9 \\
\cline { 2 - 4 } & $46-60$ & 73 & 20.9 \\
\cline { 2 - 4 } & $61-$ above & 36 & 10.3 \\
\cline { 2 - 4 } & SSCE & 128 & 36.6 \\
\cline { 2 - 4 } & ND/NCE & 135 & 38.6 \\
\cline { 2 - 4 } & BSc/HND & 59 & 16.9 \\
\cline { 2 - 4 } & Postgraduate & 25 & 7.1 \\
\hline \multirow{4}{*}{ Years of using Bank } & Others & 3 & 0.9 \\
\cline { 2 - 4 } & 1 Year & 104 & 29.7 \\
\cline { 2 - 4 } & 2 Years & 80 & 22.6 \\
\cline { 2 - 4 } & 3 Years & 48 & 13.7 \\
\cline { 2 - 4 } & 4 Years & 61 & 17.4 \\
\cline { 2 - 4 } & 5 Years - Above & 57 & 16.3 \\
\hline \multirow{5}{*}{ Occupation } & Civil Servant & 51 & 37.1 \\
\cline { 2 - 4 } & Private Employee & 65 & 25.1 \\
\cline { 2 - 4 } & Self-Employee & 125 & 30.0 \\
\cline { 2 - 4 } & Students & 95 & 3.4 \\
\cline { 2 - 4 } & Trader & 14 & 4.3 \\
\hline \multirow{4}{*}{ Gender } & Male & 177 & 49.4 \\
\cline { 2 - 4 } & Female & 173 & \\
\cline { 2 - 4 } & & & 50.6 \\
\hline
\end{tabular}

Source: Field Survey (2017)

The results shows that age bracket between $18-25$ years with $17.7 \%$ were dominant among the Jaiz Bank. Followed by $26-35$ with $28.3 \%$, again $36-45$ with $22.9 \%$ then $46-60$ with $20.9 \%$ and finally the age bracket of 61 representing $10.3 \%$.In terms of highest educational qualification the respondents holds, results shows that the dominant teachers are 
those with o- level $36.6 \%$ B.Sc./HND qualifications with $38.6 \%$, followed by those with N.C.E/ND with $16.9 \%$, next are those with P.G representing $7.1 \%$, and finally are those with other qualifications with $0.9 \%$. Regarding years of using bank $29.7 \%$ are those with 1 year using the bank, next are those with 2 years with $22.6 \%$, next are those with 3 years with $13.7 \%$, those with 4 years $17.4 \%$ and finally 5 - above years with $16.3 \%$. The final demographic information of the respondents analyzed was occupation of civil servant representing $37.1 \%$ followed by private employee with $25.1 \%$ follow by self employee with $30.0 \%$ then students with $3.4 \%$ and finally trader with only $4.3 \%$. The gender of respondent consist of male and female were male dominate with $50.6 \%$ and female with $49.4 \%$

There are different types of reliability tests, but the most widely used technique in many researches is internal consistency reliability (Litwin, 1995). The Cronbach alpha coefficient test was carried out to measure the internal consistency of the data. Table 2 present the summary of the reliability test result.

Table 2: Summary of Reliability Test Result

\begin{tabular}{|c|c|c|}
\hline Variables & Number of Items & Cronbach Alpha \\
\hline Convenience & 10 & 0.854 \\
\hline Reliability & 5 & 0.729 \\
\hline Accessibility & 10 & 0.844 \\
\hline Customer Satisfaction & 9 & 0.712 \\
\hline
\end{tabular}

Source: Field Survey (2017)

Cronbach alpha can be judged by some rules, alpha coefficient that is greater than 0.90 is recommended as excellent, more than 0.80 is categorized as good, while greater than 0.70 is acceptable, greater than 0.6 is meant to be questionable, greater than 0.5 is considered as poor, and finally less than 0.5 is generally not acceptable (John \& Reve, 1982). Reliability of 0.60 can be considered as average coefficient, whereas 0.70 could be regarded as high reliability coefficient (Hair, et al., 2006; Sekaran \& Bougie, 2010). In general, a Cronbach alpha of 0.7 has been accepted as the minimum benchmark for examining reliability. Therefore, the results of the reliability test show that, the Cronbach alpha for the variables under study reached acceptable reliability coefficient which is within the acceptable range of 0.7 .

\section{A. Regression Result}

Multiple regression analysis provides an avenue of neutrality of assessing the degree and character between independent variables and dependent variable (Sekaran \& Bougie, 
2010; Field, 2009). Three (3) predicting variables including accessibility, convenience, and reliability were examined to see their effect on customer satisfaction. Table 3 presented regression analysis of the variables under study.

The results of model summary presented in Table 3 shows a significant $R=0.470$, this implies that multiple correlation coefficients between the predictors and the criterion was $47 \%$, while $\mathrm{R}^{2}$ of 0.221 implies that predicting variables (accessibility, convenience and reliability) under the study were able to account or explain $22 \%$ variance in the dependent variable (customer satisfaction), while the remaining $78 \%$ was not captured by this study. Furthermore, Cohen and Cohen (1988) classify the $\mathrm{R}^{2}$ into three (3) categories: 0.02 as weak, 0.13 as moderate and 0.26 as substantial, in view of this classification the present study $R^{2}$ is considered moderate. The significant F-test of $(32.701, \mathrm{p}<0.000)$ signifies that the overall significant prediction of independent variables to the dependent variable, this further implies that, p-value of 0.000 has a model fitness in regressing the impact of electronic banking on customer satisfaction in the Nigeria banking industry.

Table 3: Regression Result

\begin{tabular}{|c|c|c|c|c|c|}
\hline \multirow[t]{2}{*}{ Model } & \multicolumn{2}{|c|}{ Unstandardized Coefficients } & \multirow{2}{*}{$\begin{array}{c}\begin{array}{c}\text { Standardized } \\
\text { Coefficients }\end{array} \\
\text { Beta } \\
\end{array}$} & \multirow[t]{2}{*}{$\mathbf{T}$} & \multirow[t]{2}{*}{ Sig. } \\
\hline & B & Std. Error & & & \\
\hline (Constant) & 2.580 & 0.131 & & 19.752 & 0.000 \\
\hline Accessibility & 0.107 & 0.046 & 0.159 & 2.320 & 0.021 \\
\hline Convenience & 0.179 & 0.049 & 0.273 & 3.658 & 0.000 \\
\hline Reliability & 0.058 & 0.049 & 0.090 & 1.180 & 0.239 \\
\hline 0.221 & Adj. $R^{2}$ & 0.214 & F-Stats & & \\
\hline
\end{tabular}

Note: Source: SPSS Output (2017), Dependent Variable: Customer satisfaction, Predictors: (Constant), Reliability, Accessibility, convenience

Based on the regression result in table 4.3 convenience as the predicting variable on customer satisfaction with a value of $(\beta=0.273, \mathrm{t}=3.658, \mathrm{p}<0.000)$. These indicate that convenience has positive and significant effect on customer satisfaction in Nigeria Banking industries. This implies that when Jaiz bank have enough convenience it lead to an increase in their business performance. The result further suggests that more convenience will lead to customer satisfaction. The result in table 3 shows that the hypothesis one was supported. The result of this study is consistent with the results of several studies, such as that of khalif and al-zubi (2011), Sharma and Malviya (2014), Akindele and Rotimi (2010), and Menson Auta (2007), which show that convenience has significant effect on customer satisfaction, and this 
implies that if customers of Jaiz Bank got what they want without any stress conveniently it will propel them to stick to the Bank and automatically it will make the Bank to beat competitors and achieve profit maximization which will also lead to diversification.

The next vital predictor in order of importance is accessibility with a value of ( $\beta=$ $0.159, \mathrm{t}=2.320, \mathrm{p}<0.021)$. These result shows that there is significant positive effect between accessibility and customer satisfaction in Nigeria Banking industries. The result of this study shows that the hypothesis 2 was supported. The result of this study is consistent with the results of previous studies of khalif and al-zubi (2011), Addai et al. (2015), Cheng et al. (2010), Akindele and Rotimi (2010) which show that accessibility as a significant and positive effect on customer satisfaction in the Nigeria banking industries. However, with regards to accessibility as first predicting variable under the study, results shows significant positive effect with customer satisfaction. This implies that when Jaiz bank have enough accessibility it lead to an increase in their business performance. The result further suggests that more accessibility will lead to customer satisfaction.

However, reliability as the predicting variable on customer satisfaction with the value of $(\beta=.090, \mathrm{t}=1.180, \mathrm{p}>0.239)$ shows that reliability does not have significant effect on customer satisfaction in Nigeria Banking industries. The result of this study shows that hypothesis 3 was rejected. The study result is contrary with the results of other studies such As Mawanupur (2010), Anane and Poku (2015), Menson Auta (2007), Manusamy, Chellian and Mun (2010). This implies that reliability does not add to customer satisfaction in this study, it's something else and it should be identify so customer satisfaction can be fully achieved.

\section{Conclusion and Recommendation}

The discoveries of this examination demonstrate categorically that electronic banking products have affected decidedly on the consumer satisfaction/fulfilment of the Jaiz bank and that client recognition has enormously changed because of these products. Unmistakably, every one of the destinations expressed that the investigation were accomplished. It is in this way the desire for the analyst recommendations/proposals made in light on these discoveries ought to be executed by the Bank to build efficiency and turn into a pioneer in financial service sector of the Nigerian economy. Electronic banking hones have turned into an important survival weapon and are positively changing the banking industry around the world. Today, the snap of a mouse offers bank clients services at a lower cost and furthermore engages them with extraordinary flexibility in picking merchants for their financial service 
needs. In perspective of the discoveries of this investigation it is reasoned that convenience and accessibility has huge effect on service conveyance, which will prompt enhanced consumer satisfaction. The electronic banking has enormous effect on the development of client base for the banking industry in Nigeria, through upgrading banking services accessibility and convenience to bigger populace in the nation. Reliability isn't famous among clients which accordingly came about to an irrelevant effect on the consumer satisfaction of Jaiz bank in Nigeria.

There is the need to instruct clients widely on the utilization of electronic services, for example, web banking, SMS (Mobile) banking and e-zwich, POS banking services which are not all around belittled. E-banking services ought to be produced broadly notwithstanding rivalry in the banking industry to support the weight and maintain profit. It is vital that, the bank make an e-banking unit in other to monitor progress and difficulties of such services. This will guarantee compelling and effective e-banking services. Much should be taking care of in the territory of making mindfulness about the availability and accessibility of Electronic banking products and services, particularly phone banking, how they work and their benefits. Banks ought to sort out open displays and television shows and make products available to all clients. What's more, they ought to enhance their services conveyance to legitimize the advantages of electronic banking products and services. Along these lines, clients' advantage would be stimulated.

\section{Suggestions for Future Research}

This research is very limited because it only investigates the effect of convenience, accessibility and reliability on customer satisfaction in the Nigeria banking industry. So, for the future research, it is suggested to add additional independent variable such as: technology and moderating variable such as: age and experience in order to achieve more viable result. This study focused only on one branch of Jaiz Bank, future researcher should replicate same study in other branches of different banks such as: First Bank, Zenith Bank, Diamond Banks, Guarantee Trust Bank, Union Bank and Access Bank etc. and other service industries such as: hospital, saloon, hotel, notary office etc, and at the same time in an un-service industry such as block industry, printing industry, furniture industry, mechanic industry etc, in order to get varied and objective result. Moreover, this model can be tested on other industries and cultural settings. The present study make use of multiple regression to test the study 
Pakistan Journal of Humanities and Social Sciences, 6(3), 2018

hypotheses, am suggesting future researcher should make use of Structural Equation Modeling (SEM) for more better result.

\section{References}

Al- Hajri, S. (2008). The Adoption of e-Banking: The Case of Omani Banks. International Review of Business Research Papers, 4(5):120-128).

Ali, W.D, Ibrahim, A.N and Ajagbe, S.T (2016). Role of Electronic Banking in Enhancing Human Resource Performance and Customer Satisfaction: Evidence from Guaranty Trust Bank PLC, Nigeria. International Journal of Business and Behavioral Sciences.Vol. 3, No.4; pp 36-44.

Al-Somali, SA, Gholami R, Clegg B. (2008). Internet Banking Acceptance in the Context of Developing Countries: An Extension of the Technology Acceptance Model.

Ammar S.H. (2012). Effect of E-Banking Services on Customer Value and Customer Loyalty. An applied study on Jordanian Commercial Banks. Master Thesis of Middle East University, Jordan.

Anne, R.M and Paku, A.S (2015).The Impact of Electronic Banking on Human Resources Performance in the Nigerian Banking Industry. International Journal of Economic Development Research and Investment, Vol. 3, No 2, Pp 61-69.

Balachandher, K.G, Vaithilingam S, Ismail N, Prasad, R. (2001). Electronic banking in Malaysia: Note on evolution of service and consumer reactions. Electronic banking, 3(2)135-147.

Balogun, O.J., Ajiboye, F.A. \& Dunsin, A.T. (2013). An Investigative Study on Factors Influencing the Customer Satisfaction with E-Banking in Nigeria. International Journal of Academic Research in Economics and Management Sciences, Vol. 2, No. 6, Pp. 64-73 
Baten, J.F, Kamla, M. (2010). Insights into customer motivations for switching to Internet banking. The International Review of Retail, Distribution and Consumer Research. 2003; 13(4):375-392.

CBN (2003). Guidelines On Electronic-Banking in Nigeria, available at http/www.cenbank.org

Culiberg, N.J., Lockett, A., Winklhofer, H., \& Ennew, C. (2010). The adoption of Internet financial services: A

Fornell, C. (1992). A National Customer Satisfaction Barometer: The Swedish Experience. Journal of Marketing, 56 (1): 6-21.

Gao, O. \& Owolabi, O. (2008). Consumer Adoption of Internet Banking in Nigeria. African. Journal of. Marketing Management, 4(2):116 - 124.

Godwin-Jones, R. (2001). Accessibility and web design: why does it matter?

Hackett, S., \& Parmanto, B. (2009). Homepage not enough when evaluating web site accessibility. Internet Research, 19(1), 78-87.

Haidar, R.A. (2011). Customers' Preference for E-banking Services: A Case Study of Selected Banks in Sierra Leon. Australian Journal of Business and Management Research. 1(4), 108-116.

Hair J, Black W, Babin B, Anderson R, Tatham R. (2007). Multivariate Data Analysis. 6th ed. New Jersey: Pearson Education, Inc.

Hassan, M., Hassan, S., Nawaz, M. S. \& Aksel, I. (2013). Measuring Customer Satisfaction and Loyalty through Service Fairness, Service Quality and Price Fairness Perception: An Empirical Study of Pakistan Mobile Telecommunication Sector. Science International Journal, 25(2): 971-980.

Musa, M. et al. (2015). E-banking in Transition Economies: The Case of Romania. Journal of Financial Services Marketing, 6(4):362-378.

Hurlin, M. E. (2003). An Alternative Approach in Service Quality: An E- Banking Case Study, Quality Manage, 15, pp. 41-48.

Ibok, I.N. \& Ikoh, I.M. (2011). Determinants of Customers Satisfaction with Internet Banking Services. British Journal of Art and Social Sciences, 2(4):178-186.

Jaruwachirathanakul B. \& Fink, D. (2005). Internet Banking Adoption 
Pakistan Journal of Humanities and Social Sciences, 6(3), 2018

John, F. Rotimi, Z. (2006). Relationship between Online Service Quality and Customer Satisfaction: A Study In Internet Banking, Master Thesis, Lulea University of Technology.

Jun, M., \& Cai, S. (2001). The key determinants of internet banking service quality: a content analysis. International journal of bank marketing, 19(7), 276-291.

Khalif, S. K. \& Al-zubi, N. (2011). Service Quality Evaluation in Internet Banking: An Empirical Study in India, International Journal of Indian Culture and Business Management, Vol. 2, No. 1. Pp. 34-43.

Kumbhar, V. M. (2011). Factors affecting the customer satisfaction in e-banking: Some evidences form Indian banks. Management Research \& Practice, 3(4).

Mensun, C.L. (2007). E-Banking in Malaysia: Opportunity and Challenges. Journal of Internet Banking and Commerce, 10(3): 45-54.

Mirada, M. E. (2009). An Alternative Approach in Service Quality: An E- Banking Case Study, Quality Manage, 15, pp. 41-48.

Moment, D., Singh, J. \& Sabol, B. (2013). Consumer Trust, Value, and Loyalty in Relational Exchanges. Journal of Marketing, 4(3): Pp. 15- 37.

Munusamy J, Run, E.C, Chelliah S, Annamalah, S. (2012). Adoption of Retail Internet Banking: A Study of Demographic Factors 17: 1-14.

Musiime, A. \& Ramadhan, M. (2011). Internet Banking, Consumer Adoption and Customer Satisfaction. African Journal of Marketing Management, 3(10), 261-269,

Nupur, J. (2010). E-Banking and Customers' Satisfaction in Bangladesh: An Analysis International Review of Business Research Papers, 6(4):145 - 156

Offei, I.N., Nuamah, K. (2016). The Contribution of Electronic Banking to Customer Satisfaction: A Case of GCB Bank Limited -Koforidua. International Journal of Managing Information Technology, Vol.8, No.1, Pp. 1-11.

Okibo, A. \& Warrio, S. (2010). Online Banking: A Field Study of Drivers, Development Challenges, and Expectations, International Journal of Information Management, 21, pp. 213-225

Oluwagbemi, O., Abah, J., Achimuga, P. (2011).The Impact of Information Technology in Nigeria banking industry. Journal of Computer Science and Engineering, 7(2), 63-67.

Omar, R.M and Sajuyigbe, A.S. (2015).The Impact of Electronic Banking on Human resources Performance in the Nigerian Banking Industry. International Journal of Economic Development Research and Investment, Vol. 3, No 2.Pp 61-69. 
Saha, D. \& Zhao, Y. (2005). Relationship between Online Service Quality and Customer Satisfaction. MSc Thesis Lule University of Technology

Saleem, Z., \& Rashid, K. (2011). Relationship between Customer Satisfaction and Mobile Banking Adoption in Pakistan. Journal of Trade, Economics and Finance, 2(6), 537-544.

Sekaran, U., \& Bougie, R. (2013). Research Methods for Business. A Skill-Building Approach. (6 ${ }^{\text {th }}$ Edition). Wiley Publishing.

Sharma, P., \& Singh, P. (2013). Barriers in Adoption and Service Preferences. Journal of Management, 5(1), 7-18.

Umorok, U. E. (2009), A Major Client Source to Stock Broking Firms in Nigeria. A Paper Presented during the Annual Retreat of Cash craft Asset Management Limited, Lagos.

Yan Ma, Y., \& Ding, J. (2010) "Delivering Customer Value Based on Service Process: The Example of Tesco.com”, International Business Research Vol. 3(2):131- 137.

Yau, S. C. E. (2007). Factors Affecting Customer Retention in Internet Banking among Hong - Kong Professionals and Business Practitioners

Yusif, I., \& Bala, T. ( 2015). Bankers Perceptions of Electronic Banking in Nigeria: A Review of Post Consolidation Experience. Research journal of financial and accounting, 3(2), 1-11. 